\title{
The Autonomy of Scandinavian Public Service Broadcasters During Election Campaign Periods \\ Principles and Practices
}

\author{
Kjersti Thorbjørnsrud
}

\begin{abstract}
This comparative case study explores the formal and informal principles governing election formats produced by the public service broadcasters in Sweden, Denmark and Norway. The focus is on external regulation vs. journalistic autonomy and on principles of balance and access. The conclusion is that the Scandinavian broadcasters, to a larger extent than broadcasters in other Western countries, independently control the form and content of their election formats. This journalistic autonomy, however, has brought about election formats governed by different principles of access. The Danish and Swedish formats are based on a moderate stopwatch logic, whereas the election formats in Norway center on criteria of audience appeal, resulting in a model of access disproportionately favoring certain political parties. The high degree of journalistic control of election formats in Scandinavia, paired with the low control of political parties encourage a discussion of some of the central premises in the Democratic Corporatist Model.
\end{abstract}

Keywords: election coverage, regulation, journalistic autonomy, broadcasters, models of media and politics

\section{Introduction}

Debates between incumbents and their rivals and the journalistic interrogation of party leaders on TV during election campaign periods usually attract large audiences (Coleman 2000). For broadcasters, these media events are attractive to organize, produce and transmit. For political leaders, the stakes are high when taking part in such formats, and they share an interest in influencing their form and content. From a public interest perspective, these events are argued to be of such vital importance in a democracy that they should be governed by extraordinary principles of fairness and balance so as to avoid biased election coverage (McQueen 1992, Coleman 2000).

The institutionalization of control of the form and content of these formats can be regarded as the results of negotiations, struggles and concessions on the part of actors within the political and journalistic fields. Who governs the premises of these events, and according to what kind of principles: Media professionals, political parties or a more abstract "general interest" expressed through legislation? 
The present article probes these questions by asking how TV election formats produced by the public service broadcasters in Sweden, Norway and Denmark are regulated and controlled. It further explores what kinds of principles of balance and access govern these formats. Through the construction of three ideal typical control regimes of election coverage, the article asks whether there is a "Scandinavian model" pertaining to the regulation and control of election formats on TV. To provide a contrasting comparative background for the Nordic cases, examples of control regimes of televised election debates from countries with models of media and politics different from the Nordic countries, such as Britain, France and the US, are highlighted.

Election campaign periods in a wide range of countries are times of extraordinary state regulation of broadcasters, leaving political parties with more control of audiovisual output than in regular times (Coleman 2000, Kaid and Strömback 2008). This is also the case for countries with so-called liberal media models that traditionally prevent substantial state intervention (Hallin and Mancini 2005). The Scandinavian countries, on the other hand, are, as Hallin and Mancini (2005) argue, typically representative of countries with a Democratic Corporatist model, combining strong journalistic professionalism with active state intervention in the media sector (Hallin and Mancini 2005: 197). Their model is in general judged to be valid in a broad study comparing the media models in the Nordic countries (Strömback et al. 2008).

According to Hallin and Mancini, the model of broadcaster governance in the Nordic countries is intertwined with civic and parliamentary models of control, providing a substantial role to organized political forces, either in the form of political parties (the parliamentarian model) or in the form of other social interest groups (the civic model) (Hallin and Mancini 2004: 165). Exploring the degree of journalistic control over the form and content of election formats compared to the influence of political parties is well suited to a discussion of some of Hallin and Mancini's key assumptions regarding the influence of parties and other organized forces within the Democratic Corporatist model.

Even if there has been a strong call for comparative studies of political communication (Blumler 2004; Aalberg 2010), there is a lack of comparative studies investigating the institutional premises behind election coverage. Strömback and Aalberg (2008) and Strömback and Dimitrova (2006) have carried out comparative content analysis of election coverage, but apart from some noteworthy exceptions (Semetko and Blumler: 1991; Semetko and Canel: 1997), these studies do not map the actual formal and informal control regimes governing election coverage on television. the actual formal and informal control regimes governing election coverage on television. The present article fills this gap in the research ap institutional analysis of both formal and informal control regimes of broadcast election formats.

\section{Research Design}

This is a comparative case study of the Public Broadcasters DR (Danmarks Radio) in Denmark, SVT (Sveriges Television) in Sweden and NRK (Norsk rikskringkasting) in Norway. All three are financed by license fees and all have played a paramount role in the media landscape of their respective countries.

To make a comparison feasible, the focus is on the governing principles behind election formats and not on regular news. Election formats are defined as programs produced 
with an upcoming election in mind, normally featuring debates between politicians running for office and/or interrogations of political leaders by journalists. In both DR, SVT and NRK, there is a solid tradition of clearing airtime in primetime for such formats. The aim of the present analysis of these formats is to decide whether they are controlled by external actors and institutions and whether a stopwatch logic, a proportional model or other selection criteria guide the allocation of airtime to political parties.

The data consist of semi-structured interviews, document analysis and output analysis. DR, SVT and NRK normally appoint a project leader to direct the coordination and planning of the different types of election formats to be produced well in advance of an upcoming election. These leaders have been vital informants ${ }^{1}$; they were asked about the role of public broadcasters, journalistic independence, program ideas and the status of editorial guidelines related to election coverage. The interview data have been triangulated with document and text analysis. The documents researched range from laws on PBS broadcasting, official editorial guidelines, evaluations and reports, and websites to internal memos. ${ }^{2}$ The output analysis builds on the recording of election formats transmitted on national television in SVT, DR and NRK in primetime during the campaign period. The focus is on the premises underlying the election formats produced by the three broadcasters during the four-week campaign period preceding the elections of 2006 (Sweden) and 2007 (Norway and Denmark). In Sweden, the campaign led up to a combined national and regional election, whereas in Denmark a national election was held in 2007. The election in Norway in 2007 was regional. The validity of the Norwegian data was strengthened by the fact that the NRK relied on the same type of election formats in 2007 as they had done in previous national election campaign periods (Thorbjørnsrud 2009).

To provide a contrasting background for the Nordic cases, regulations and editorial guidelines concerning broadcast election coverage in France and Britain have been studied. Additionally, the organization of the aired US presidential debates has been explored. Finally, interviews have been conducted with a political reporter at French Tele 2 and with the chief political advisor at the BBC.

\section{Types of Control Regimes for Audiovisual Election Coverage}

During election campaign periods, the journalism behind TV and radio broadcasts in many countries follows principles that are made more explicit than usual. The conventional, day-to-day, implicit journalistic judgments governing TV production are supplemented and partly replaced by formal principles. The principles in action aim at a fair and balanced coverage, avoiding biases that favor some parties and candidates over others (Dahl 1998; Graber et al. 1998; Coleman 2000; Esaiasson and Håkansson 2002).

Both the way principles of fairness and balance are operationalized in practice and the source of these principles vary. One model builds on a principal of equal access for all eligible candidates and parties irrespective of their power base or popular support (McQail 1992). When strictly applied, this stopwatch balance ensures that each party and candidate is given exactly the same amount of airtime. Another logic builds on a principle of proportionality: Parties' proportions of votes in the last election, their number of seats in parliament, and/or their support in current opinion polls are taken into account when television airtime is allocated (McQuail 1992). 
Further distinctions need to be made between models in which access is regulated by law, is under informal political control, or is based on journalistic autonomy.

The obvious example of a country with election formats under legislative control, based on a stopwatch model, is France, where election coverage is under the scrutiny of the government appointed Conseil Supérieur de L'audovisuel. ${ }^{3}$ During the election campaign period, this regulatory agency lays down rules for the allocation of airtime for broadcasters pursuant to the law on audiovisual media. ${ }^{4}$ The principles applied are based on a strict stopwatch logic whereby each eligible candidate has the right to the same amount of airtime.

Other countries, such as the UK, have a more complicated combination of juridical control and self-regulation. Public Service broadcasters are obliged by law ${ }^{5}$ to formulate guidelines for the election coverage in accordance with any views expressed by the Electoral Commission ${ }^{6}$. The formulation of rules is left to the broadcasters themselves. Thus, the British public service-broadcasters are allowed a much greater degree of self-regulation than their French counterparts, and they have guidelines that allow for a proportional model, where the main parties and candidates receive more attention than the small ones. The level of attention from society, and the fact that editorial guidelines are under scrutiny by The Electoral Commission, however, contributes to a high awareness among the broadcasters as to how the obligation to produce a balanced election coverage is met. ${ }^{7}$

A more extensive, informal way of diminishing the power of broadcasters as producers and moderators of TV debates is for political parties to take direct control of the organization of the debates themselves. This party political control over election debates is found in the US. Through the Commission of Presidential Debates, the Republican and Democratic parties govern the length of candidate's airtime, their responses and rebuttals, who the moderator will be and what role he/she will play, etc. The Commission $^{8}$ is, since its inception in 1988, headed by former chairpersons of the Republican and Democratic parties (Coleman 2000). The absence of formal regulation in the US implies that candidates from parties other than the Democrats and the Republicans are excluded from the central televised election debates.

In the last type of control with access to televised election formats, media professionals control the premises regarding both dramaturgy, topics up for discussion and access for eligible candidates. This journalistic type of control over the form and content of election formats can follow different paths: Broadcasters can commit themselves to follow certain explicit guidelines - such as principles for allocation of airtime - through self-regulation. The other option is to stick to conventional, implicit and nontransparent journalistic judgments in the production of these formats. Journalists' ability to govern the content and form of election formats, however, does not depend only on formal autonomy. The informal journalistic control over, for example, election debates is a type of control that materializes through accessible politicians who actually accept the premises for debates set by media professionals.

In the next section, the article explores what type of formal and informal control regimes for election formats exist in a Scandinavian context. 


\section{Autonomous Scandinavian Broadcasters}

Fueled by the advent of competitive private TV channels during the 80 s and 90s, professionalization and popularization processes have marked both the Swedish, Danish and Norwegian public service broadcasters. Expansions to new media platforms have characterized the most recent years (Syvertsen 1997; Djerf Pierre 2000; Hjarvard 2006). The election coverage of the three broadcasters has been significantly influenced by these trends, not least because private channels have produced election debates directly competing with the productions of the public service broadcasters (Thorbjørnsrud 2009). But as reported by the project leaders at DR, SVT and NRK alike: Having high-profile election coverage still is an important part of the PBS identity. In the Scandinavian countries, this priority of election coverage exists without any juridical or external regulation involvement. The laws covering the premises for the license to broadcast in the three countries do not mention election coverage ${ }^{9}$. Nor are there external institutions with the mandate to interfere with the editorial decisions of the broadcasters. There are indeed media authorities and councils occupied with monitoring the ethical and democratic obligations of the broadcasters in all three countries, but their mandate is advisory rather than executive, and there is no tradition for interfering in editorial choices and content production ${ }^{10}$.

Hence, the informants make clear that it is and ought to be the right of the broadcasters to independently decide the character of their election programs, in terms of both form and content. The Swedish project leader is representative when he dismisses any kind of external regulation of the election coverage:

We don't have that! [...] It's our own. It is, so to speak, the broadcaster's own arrangement. Our independence is, I would say, very substantial. And the political parties and others, that is - they may have objections, they can be furious after the fact and so on, about certain issues - but there are just no attempts to control this.

The project leaders underscore the fact that the election coverage is not based on any kind of mutual agreement with the political parties in advance of the election campaign period. Rather, the political parties are informed about the broadcasters' program arrangements. The Swedish project leader refers to previous controversies between political parties and journalists over the terms of election coverage as a settled dispute where a strong journalist profession has gradually succeeded with their arguments about the importance of journalistic independence. The accounts of the project leaders demonstrate not only that DR, SVT and NRK base their election coverage on a high degree of formal autonomy, but that they also rely on a high degree of informal control, based on accessible politicians who are willing to participate on the journalists' premises. According to the Norwegian project leader:

The cooperation between journalists and politicians is very informal. I can call the Ministry of Finance and quickly get an appointment with the Minister to participate on radio or TV [...]. Our access to politicians is amazing - we're never turned down.

The project leaders claim that it would be out of the question to broadcast debates set up and arranged by the parties themselves, as is done with the presidential debates in the US. But whereas SVT and NRK emphasize the fact that politicians have come to accept 
that they do not have a say regarding the way televised election formats are produced, the Danish project leader actually gives an account of how the Danish parties aimed at influencing the terms for a debate involving the PM and the leader of the main rival party:

For a long time, the idea about the debate between the two party leaders was difficult to realize. The Prime Minister was not interested, because the Social Democrats had a very charismatic and skillful communicator as their leader. As such, he had reason to believe he had little to gain from participating in such a debate.[...] However, after long negotiations, the parties in the end suggested they would arrange the debates themselves with a live audience, and then TV 2 and DR would be allowed to broadcast the debates. But for us it would be completely unthinkable to let the politicians control the debates in this way!

The dispute was settled in favor of DR, the politicians agreed in the end to participate in the debate produced by DR, but without a live audience.

\section{Explicit Election Guidelines?}

Having established that the Nordic broadcasters are formally autonomous regarding their election coverage, and that they also to a great extent establish the premises for the participation of politicians in studio debates informally, I will now explore whether the same broadcasters commit to explicit election guidelines through self-regulation. All project leaders underscore that they feel certain obligations with regard to the scope of the channels' election formats, in particular with regard to balance. The Danish editorial leader, after having emphasized that she would never accept direct interference from politicians in DR's editorial policy, quickly adds that DR needs to adhere to its particular role as a PBS, and that during election campaigns DR pays particular attention to principles of fairness and balance:

We have guidelines requiring that all parties be presented on TV. Even small parties that we know will not get into Parliament; they are entitled to the same thorough treatment. It's not only about airtime; it's also that we should take them seriously, spend time on them - that they should be invited along.

As referred to by the Danish project leader, election coverage is mentioned in the general editorial guidelines adopted by $\mathrm{DR}^{11}$. They state that during elections and referendums, DR should meet obligations such as providing the public with balanced information and critical investigations of candidates and election issues. The guidelines are to some extent more specific than the guidelines in SVT and NRK; unlike the other two TV channels' codes, DR's guidelines mention election coverage in particular, and they contain a rule about the right of each political party to transmit a self-produced video. This, in other words, is DR's version of 'party political broadcasts', a practice that the project leader in DR dislikes:

[...] we have a backlog - something that we've tried to abolish, but that I guess is mentioned in our guidelines, which states that: Each party is entitled to a presentation and to disseminate its own party's uncut or unedited messages. But there is no mention of time. Before it was normal to give them 5 minutes, but now we have cut each party's presentation down to 3-minute videos. 
These unedited party political broadcasts then, account for a very tiny proportion of the election coverage of the Danish broadcaster. The latitude for implicit journalistic judgments, not covered by the guidelines, is wide. This is illustrated by the reference to a 'gray zone' of editorial decisions related to the balance of the election coverage, a balance the project leader acknowledges could be disputed:

Earlier the rules were interpreted very strictly. All parties were to have equal time to speak - we timed them. We don't do that anymore. We a have a modus Vivendi where we - there's a lot of journalistic judgment to it. We evaluate: What are the most important issues? How significant is the party? How significant are they to the voters? In our view - because this is after all a subjective evaluation.

The Danish project leader is the only one of the interviewees who expresses the idea of the parties' right to be presented on the air. Her two colleagues are vaguer in their formulations, even though they too assume that public broadcasters have a certain kind of responsibility during election campaigns, broadly linked to democracy and general ethical principles. In their codes of conduct, SVT states its public service mission in general terms. SVT should: 'Provide news, stimulate debate, comment and shed light on events and happenings, and thereby provide the necessary information for citizens $[\ldots]^{12}$. On SVT's official web page ${ }^{13}$ it is stressed that this announcement does not say anything about how programs should be produced. The broadcaster defines public service this way:

\section{Lately, SVT has used the concept 'free television' to explain public service. By 'free" we do not mean free of charge, but free from the influence of political and commercial forces.}

Unlike the Danish, the Swedish guidelines do not mention election coverage in particular. Prior to the election campaign period in Sweden in 2006, however, SVT management issued a statement saying that it was the duty of SVT to ensure that all publications, on all platforms, are 'conducted in an impartial, balanced and comprehensive manner'. In line with the definition of "free television" the decree does not go into detail about how the programs should ensure balance and impartiality in practice. In this document it is stated in the end that: "Beyond judicious attention to the above, there are no limitations as to the participation of politicians or other representatives of political views within the election"14. The principles in SVT's official statements of their obligations are, in other words, broad. There is an emphasis on sound editorial assessment rather than on specific editorial guidelines. This is expressed by the project leader in the following response in an interview published on SVT's own official website prior to the 2006 election campaign period:

- How do you make sure the parties get equal attention in your election coverage?

- In our news coverage, news assessment determines which political parties and events are covered. When it comes to election debates, all parties that are relevant to the questions on the agenda $[\ldots]$ are to be invited. ${ }^{15}$

Like DR and SVT, the Norwegian NRK has statutory rules ${ }^{16}$ that in broad terms define NRK's role as a public service broadcaster. They hold that NRK should communicate vital or important information to the public as well as arrange debates concerning society in accordance with core democratic values. Furthermore, NRK's programming is 
expected to maintain high ethical standards and over time to be balanced (paragraph 3.3). These codes are rather unspecific and downplay the principle of balance more than the Swedish and Danish codes do by reducing it to a goal that is to be fulfilled over time, not in single programs or in single program series. The statutory rules were supplemented in 2007 with "NRK-plakaten", a poster confirming the statutory rules. Here election coverage is discussed as follows: "NRK should have a broad and balanced election coverage. All parties of a certain size should normally be mentioned in the editorial election coverage". The mentioning of election coverage made a stir among journalists and editors in NRK when the poster was introduced, declaring that they refused any type of external interference in their editorial decisions. Their arguments made the Government modify the words of the original text, resulting in the indeed vague sentence in the poster about normally mentioning parties of a certain size. How they should be mentioned, the amount of airtime to be allocated, and according to what principle of balance, then, are issues still up to NRK to decide.

To sum up: Neither NRK, DR nor SVT have detailed election guidelines regarding program content; their codes are much less detailed than the editorial guidelines of a public service broadcaster like the BBC, or the meticulous directions governing French audiovisual election coverage.

\section{Balance in Practice - Election Formats in DR, SVT and NRK}

In spite of the wide room for implicit journalistic judgments, all project leaders underscore that it actually is important that their election formats fulfill principles of balance and fairness. The question, then, is how 'balance' is operationalized in practice and combined with the vital demand for a large audience predominant in NRK, SVT and DR. This section probes the question by exploring principles of selection as they materialize in the actual election formats broadcast in primetime.

SVT had the largest and most complex election coverage of the three countries. In 2006, SVT broadcast almost 300 hours about the election. ${ }^{17}$ Two central program series aired during primetime were presented as "investigative" and critical". One series consisted of seven live interrogations of party leaders, each lasting 60 minutes. The other program series consisted of 60 minute documentaries focusing on one political party in each program, with the aim of revealing internal conflicts within each of the Swedish parties represented in parliament. The documentaries made a stir among the Swedish political parties; they feared a negative focus just before Election Day, the project leader stated:

[...] our investigations are broadcast closer to Election Day than before. This has often been perceived as very sensitive by the political parties. If you stumble close to the election, things can actually happen that can change the polls in quite a short amount of time.

SVT in addition produced live debates in various regions of Sweden where a number of participating politicians from the region debated in front of a live audience, broadcast during primetime. SVT finally produced one Prime Minister Duel between the incumbent and his chief opponent. According to established tradition, the final production relating to the election was a debate with all party leaders. 
The governing selection principle behind more than two of three of the election formats in primetime was based on a variant of the stopwatch logic, implying that all the Swedish Parties in parliament were presented and given the same amount of focus and time, however critical, in one program each.

At DR, the main idea behind the election formats, according to the project leader, was to produce programs that were esthetically pleasing, fulfilling criteria of being 'good $\mathrm{TV}^{`}$ and at the same time offering space for politicians to convey their messages in full. DR made less use of experts in the studio than they had done before; they wanted easily accessible formats and not 'high brow' discussions. The slogan was 'nicer to watch, easier to understand'. The project leader described the ideas as such:

We made it look more spectacular; it looked better, was more attractive, more intimate. At the same time we worked on more substance. For instance, we had the two candidates for Prime Minister - they debated for an hour before they were cut off. And they discussed with each other.

The central election format was a program series that presented the politics of each Danish party represented in parliament, called 'Meet the parties'. During the program, the party-produced video was shown. Apart from this format, DR broadcast the 60-minute duel between the incumbent and his main rival. As with SVT and NRK, the election coverage concluded with a debate between all leaders of the political parties.

The election coverage in DR was not as comprehensive as that of SVT, and it was acknowledged that the coverage did not entail a critical or investigative approach to politics. However, the election formats in primetime on DR were all built on the same basic principle of selection: equal time for each party in primetime, with the exception of the one prime minister duel, a format that the project leader in DR explicitly described as "not to the advantage" of all the political parties not represented in that duel.

The Norwegian broadcaster built on old and well-known election formats in their 2007 election coverage. NRK produced two election formats in primetime national television. The first was based on duels between top politicians and transmitted during primetime twice a week, each program lasting 20 minutes. The evaluation of previous election duels formed the premises for the duels produced in 2007. The basic premises are presented in this excerpt from an evaluation made by the editor of this debate format:

Two years ago we saw that duels between the top politicians generally produced the best ratings. (...) TV 2 often wanted the same politicians to participate in their debates as we did - on the same day - and therefore 90 minutes before us, something that would have made our debate look like a re-run.

This happened the first time on the day the campaign kicked off, when both TV channels had booked a Prime Minister debate between the prime minister and the leader of the opposition. After a lot of back and forth we said no to this debate, and instead went for the opposition leader and the head of the Progress Party. And we won the battle with TV 2 with twice as many viewers...

Conclusion: After a while we made it clear to the politicians that we did not wish to use them in our programs if they participated in exactly the same setting on TV 2 earlier in the evening. 
This evaluation points to central aspects concerning the main election format in NRK; it was strongly focused on individual participants, more so than on topics and parties, and highly centered on competition for high audience numbers. The many duels between different constellations of the prime minister, party leaders and other central politicians are specific to NRK. In SVT and DR only one duel with the prime minister was produced. In the Norwegian election coverage, however, the prime minister in the last elections was the political leader most frequently participating in debates.

The other main format with which NRK chose to continue was a debate program called 'People's meetings'. These were debates lasting 45 minutes, aired once a week, where different combinations of top politicians as well as local candidates met to discuss topics high on the political agenda in meeting halls around in the country. The debates were conducted in front of a live audience and they were split up by slots of entertainment. The idea was to combine political discussion with entertainment in a lively setting, the project leader explained. Like SVT and DR, NRK concluded its election coverage with a final party leader debate.

A modified kind of stopwatch logic still exists as a baseline for the election formats in primetime in SVT and DR - 'stopwatch' in the sense that all eligible political parties are given full focus in one program each in the most central election formats in primetime. In NRK, on the other hand, broadcasts based on this principle of representation were characterized as 'ceremonial' and outdated. For a decade NRK has instead produced debates that are based on participation from politicians, where the most important selection criterion is their quality as interesting debaters, rather than their positions or what kind of party they represent. Neither politicians nor the audience know beforehand who the debaters will be or which topics they will discuss. The two formats that NRK produced during primetime on national TV thus diverged greatly from the stopwatch model. The logic of selection comes closer to a form of proportional representation for the parties. However this was not proportional representation strictly defined, as the parties and their leaders were not allowed on the air according to their size or popular support. Rather they participated according to a logic that would end up selecting the biggest parties disproportionally frequently; they got more time on the air than their electoral support suggested (Thorbjørnsrud 2009). Also those parties with the "hottest' party leaders were overrepresented on the air to the disadvantage of smaller parties or bigger parties with leaders lacking the ability to make what was regarded as ' $g o o d$ TV'.

It is important to note that this practice could not exist without compliant politicians, both of whom accepted the premises and were willing to alter their time schedules to come to the studio at short notice, as opposed to the situation in Denmark, where DR actually had to go into negotiation processes in order to get the most attractive political leader - the prime minister - in a debate.

\section{Discussion:}

\section{Autonomous and Strong Scandinavian Public Broadcasters}

The present article has explored the degree to which the public broadcasters in Sweden, Denmark and Norway are autonomous regarding formal and informal control of the premises for their election coverage. The study has focused on the production of election formats in primetime, and has asked in what way these formats are produced with refer- 
ence to explicit rules or guidelines, and whether or not these guidelines are formulated by external actors and institutions. The conclusion is, first, that the Nordic broadcasters, to a larger extent than broadcasters in many other countries, independently control the form and content of their election formats. This journalistic autonomy, however, has brought about election formats governed by different principles of access. The Danish and Swedish formats are based on modified stopwatch logic, whereas the election formats in Norway center on criteria of audience appeal, resulting in a model of access that disproportionately favors certain political parties.

The comparatively high degree of journalistic control of election formats in Scandinavia, paired with the low control of political parties, encourage a discussion of some of the premises of the Democratic Corporatist media model as it is outlined by Hallin and Manciny (2005). According to Hallin and Mancini, public service broadcasting in the Nordic countries is characterized by strong state regulation and the influence of organized interests (like political parties), combined with high professional autonomy. Concerning possible differences between the three countries, Hallin and Mancini describe Sweden as the broadcaster with the highest degree of autonomy from party politics, whereas the broadcasters in Denmark and Norway are described as probably shading more toward a parliamentary model [...] (Hallin and Mancini 2005: 169). The assumed difference between the three broadcasters is not supported by the present study. Moreover, with regard to election coverage, the high degree of journalistic autonomy of broadcasters in the Scandinavian countries surpasses the autonomy of broadcasters operating both within the North Atlantic or liberal model and the Mediterranean or Polarized Pluralist model. The most conspicuous characteristic of the premises for the election coverage of the Scandinavian broadcasters is the fundamental belief in program productions based on journalistic independence, free from external interference. The principle of self-regulation stands strong, and is not challenged by political parties. In short, political parties in the Scandinavian countries appear to have less influence over the terms and conditions of election coverage than their counterparts in other countries. This conclusion is based on a case study focusing on only one special part of the program production of public service broadcasters, it indicates nevertheless the need for future studies exploring whether the status of organized interests within the democratic corporatist model should be toned down.

The claim that the production of election formats is based on a high degree of formal and informal autonomy fits well with other studies of the development of political journalism in the Nordic countries. This research emphasizes that the approach to politics in PBS in recent decades has been marked by a critical and independent stance, combined with the skilled and active use of editing processes and formatting (e.g., Hjarvard 2006, Dierf-Pierre 2000).

As mentioned, the present study of the election formats in SVT, DR and SVT indicates that different principles of balance and practices of predictability have taken hold in the three broadcasters, with a modified version of a stopwatch logic still reigning at SVT and DR. This logic has largely been abandoned at NRK to the advantage of a logic favoring the parties in power and parties with leaders who are assumed to have a high audience appeal. One hypothesis explaining these differences is that politicians in the three countries to various degrees enter into negotiations with the editorial leaders over the premises of the election coverage. Another hypothesis is that classic PBS 
ideals have a stronger footing at DR and SVT than at NRK (Larsen 2008). This last hypothesis points to the need for further comparative and institutional studies that look more deeply into the independent variables explaining the possible differences between Scandinavian public broadcasters.

\section{Notes}

1. The informants were: NRK project leader 2007 Per Arne Bjerke, interviewed18 Dec. 2007; DR project leader 2007, Naja Nielsen interviewed 5 Feb. 2008; SVT (KW - right?) project leader 2006, Kent Wännström, interviewed16 Dec. 2007. In addition a Danish election journalist took part in the interview in DR, the program director at NRK was also interviewed 6 May 2006.

2. See Appendix 1 for a list of the documents used. Few Danish written reports and evaluations about the 2007 election coverage existed at the time the research took place. To estimate the validity of the interview data, a team of Danish editors and journalists from DR were asked to comment on the results at a seminar held in Oslo in September 2008. They confirmed the validity of the accounts of the Danish election coverage presented here.

3. http://www.csa.fr/infos/controle/television_pluralisme_accueil.php Accessed 3 July 2010.

4. http://www.csa.fr/multi/role_sanctions.php?10=UK Accessed 3 July 2010.

5. In "The Political Parties and Referendums Act 2000" and "The Communication act 2003".

6. http://www.electoralcommission.org.uk/ Accessed 3 July 2010.

7. Interview with Chief Political Adviser in the BBC 16 April 2008.

8. http://www.debates.org/pages/news_111907.html. Accessed 20 March 2010.

9. The laws in question are the Danish "Radio og TV-loven LOV nr 439 af 10/06/2003" (The Radio and TV Law of 10 June 2003) the Swedish "Radio och TV-lagen 1996:844) (The Radio and TV Law), and the Norwegian "Lov om Kringkasting Lov 1992-12-04 nr 127” (The law on Broadcasting).

10. In Denmark, the government-appointed advisory council is called 'Radio and tv-nævnet' (see: http:// www.mediesekretariatet.dk/omrtv.htm), In Sweden 'Granskningsnämden' (see: http://www. grn.se/ (11.11.03) and in Norway 'Kringkastningsrådet' http://www.nrk.no/informasjon/organisasjonen/1386146.html accessed7 Mar 2010). Media Authorities such as The Norwegian Media Authority (Medietilsynet) in Norway (http://www.medietilsynet.no/accessed 19 Jan 2010 ) and the Swedish Broadcasting Authority (http://www.radioochtv.se/ accessed 22 Jan 2011) also monitor the broadcasters' more general fulfillment of their tasks, but they have never interfered in the production of news or election formats in the three countries.

11. DRs Programetik 2007, paragraph 15.

12. Reproduced from Peterson et al. (2006).

13. http://www.svt/jsp?d=60806\&a=707572 Accessed 19 June 2009.

14. SVT:s riktlinjer inför allmänna valen 2006 (SVT Guidelines for the 2006 election).

15. http://svt.se/svt/jsp/Crosslink.jsp?d=54029\&a=620230\&lid=puff_620193\&lpos=lasMer Accessed 19 June 2009.

16. Vedtekter for NRK AS. Last changed 30 April 2005.

17. Sveriges Televisions Pulic Service redovisning 2006:55.

20. Program host Viggo Johansen, interviewed 23 Aug 2007.

\section{References}

Aalberg, T., \& T. Brekken (2007) 'Når spill og enkeltepisoder blir viktigst', In Den medialiserte politikken, A. Todal Jenssen and T. Aalberg (eds.) Oslo, Universitetsforlaget.

Aalberg, T., \&. J. Curran (eds.) (2010) How Media Inform Democracy. A Comparative Approach. New York, Routledge.

Blumler, J.G., \& M. Gurevitch (2004) State of the Art of Comparative Political Communication Research: Poised for Maturity?, in F. Esser \& B. Pfetsch: Comparing Political Communication: Theories, Cases and Challenges. Cambridge: Cambridge University Press.

Coleman, S. (2000) 'Meaningful Political Debates in the Age of Soundbite', in Stephen Coleman (ed.) Televised Election Debates: International Perspectives, London, Palgrave Macmillan.

Dahl, R.A. (1998) On Democracy. New Haven, Yale University Press.

Djerf-Pierre, M. (2000) 'Squaring the Circle: Public Service and Commercial News on Swedish Television 1956-99’, Journalism Studies 1: 239-260. 
Kjersti Thorbjørnsrud The Autonomy of Scandinavian Public Service Broadcasters During...

Esaiasson, P., \& N. Håkansson (2002) Besked ikväll!: valprogrammen i svensk radio och TV. Stockholm, Stiftelsen Etermedierna i Sverige.

Graber, D.A., D. McQuail, \& P. Norris (1998) 'Introduction: Political Communication in a Democracy', in D. McQuail D. Graber, \& P. Norris: The Politics of News: The News of Politics. Washington: CQ Press.

Hallin, D.C., \& P. Mancini (2005) Comparing Media Systems: Three Models of Media and Politics. Cambridge: Cambridge University Press.

Hjarvard, S. (2006) 'Tv-nyheder', in Hjarvard, S. (ed) Dansk TV's historie. Frederiksberg: Samfundslitteratur. Kaid, L., \& Strömbäck, J. (eds.) (2008) “A framework for Comparing Election News Coverage around the World", In The Handbook of Election News Coverage Around the World. New York: Routledge.

McQuail, D. (1992) Media Performance: Mass Communication and the Public Interest. London: Sage.

Norris, P., J. Curtice, D. Sanders, \& H.A. Semetko (1999) On Message: Communicating the Campaign. London, Sage Publications.

Patterson, T.E (1994) Out of Order. New York: Vintage Books.

Semetko, H.A., J.G. Blumler, M. Gurevitch, D.H. Weaver, S. Barkin, G. Cleveland (1991) The Formation of Campaign Agendas: A Comparative Analysis of Party and Media Roles in Recent American and Brittish Elections. Hillsdale, Erlbaum.

Semetko, H.A., \& M.J. Canel (1997) ‘Agenda-Senders versus Agenda-Setters: Television in Spain’s 1996 Election Campaign’, Political Communication 14(4): 459-479.

Strömbäck, J., \& T. Aalberg (2008) 'Election News Coverage in Democratic Corporatist Countries: A Comparative Study of Sweden and Norway', Scandinavian Political Studies 31(1).

Strömbäck, J. \& D.V. Dimitrova (2006) 'Political and Media Systems Matter: A Comparison of Election News Coverage in Sweden and the United States, The Harvard International Journal of Press/Politics, 11(4): 131-147.

Strömbäck, J., M. Ørsten, \& T. Aalberg (eds.) (2008) Political Communication in the Nordic Countries: An Introduction'. Göteborg: Nordicom.

Swanson, D.L. (2004) 'Transnational Trends in Political Communication: Conventional Views and New Realities', in Esser, F. \& Pfetsch, B. (eds.) Comparing Political Communication: Theories, Cases, and Challenges. Cambridge: Cambridge University Press.

Syvertsen, T. (1997) Den store TV-krigen: norsk allmennfjernsyn 1988-96. Bergen-Sandviken: Fagbokforlaget. Syvertsen, T., \& H. Bastiansen (1994) 'Towards a Norwegian Television History', in Bondebjerg, I. \& F. Bono (eds.) Nordic Television: History, Politics and Aesthetics. København: Sekvens Special Edition.

Thorbjørnsrud, K. (2009) Journalistenes valg. Interaksjon, produksjon, iscenesettelse. Oslo: University of Oslo (Phd thesis).

KJERSTI THORBJØRNSRUD, Ph.D., Senior Reseacher, Department of Media and Communication, University of Oslo, kjersti.thorbjornsrud@media.uio.no 


\section{APPENDIX 1}

\section{Official Norwegian NRK documents and NRK web pages}

Vedtekter for NRK AS. Fastsatt i konstituerende generalforsamling 30.april 1996. Endret i generalforsamling 14.juni 2004.

Lov om kringkasting. Lov 1992-12-04 nr 127

NRK-plakaten

Valgredaksjon EN. http//www.nrk.no/nyheter/innenriks/valg/valg_2005/4910253.html Accessed 04.23.2007

Folkemøter. http//www.nrk.no/nyheter/innenriks/valg/valg_2005/4946053.html Accessed 04.23.2007

NRK-valg i alle kanaler http://nrk.no/nyheter/innenriks/valg/val_2007/1.3236478

\section{Internal NRK-documents}

Memo: Notat NRK Kringkasting. 09.25.2007. Sak: Valgevaulering

E-mail 08.08.05 from editor of the debate program in Redaksjon EN.

\section{Swedish official documents and web pages}

Radio och TV-lagen (1996: 844)

SVT:s riktlinjer inför allmänna valen 2006 (SVT Guidelines for the election 2006)

Sveriges televisions public service-redovisning 2006

Valet i SVT 2006. Redaktionernas utvärderinger (The election in 2006, evaluations from the production-teams

Tio frågor om SVT:s valbevakning... http://svt.se/svt/jsp?d=54029\&lid=puff_620193\&lpos=lasMer. Accessed 04.15.2007

Valet I SVT http://www.svt.se/svt/jsp?d=50614

\section{Danish official documents and web pages}

Radio og TV-loven. LOV nr 439 af 10/06/2003 (The radio and TV-Law)

DRs programetik 2007. (Editorial Guidelines)

Valget på DR:http://www.dr.dk/Nyheder/Temaer/Politik+temaer/2007/Valg/. Accessed 13.10.2008.

"Skarp kritikk af valgaften på tv". http://www.journalisten.dk/skarp-kritik-af-valgaften-pa-tv. Accessed 13.10.2008.

\section{French official documents and web pages}

Conseil supérieur de l'audiovisuel: http://www.csa.fr Accessed 10.04.2007.

Communiqués de presse: Election du president de la Republique: bilan de l'application du principe d'équité. Publisert 27.03.07. Accessed 10.04.2007.

Conseil supérieur de l'audiovisuel :"Guide d'application de la recommandation relative à la campagne en vue de l'élection présidentielle de 2007."

Bipolarisation, quand tu nous tiens.... http://medias.blog.lemonde.fr/category/debats-televises/ Publisert 27.02.07. Accessed 10.04.2007.

\section{British official documents and web pages}

BBC Editorial Guidelines: http://bbc.co.uk/guidelines/editorialguidelines Accessed 04.07.08

Election Guidelines for the election held on 1st of May 2008: http://www.bbc.co.uk/guidelines/editorialguidelines/advice/election Accessed 04.07.08

The Electoral Commission: http://www.electoralcommission.org.uk/. Accessed 04.07.08

The Electoral Commission Factsheet: Party political broadcasts.

Election Guidelines 3rd May 2007 http://www.bbc.co.uk/guidelines/editorialguidelines/advice/election/. Accessed 04.07.08

\section{US web pages}

Commission on presidential debates:

http://www.debates.org/ Accessed 15-04.2007

http://www.debates.org/pages/news_111907.html. Accessed 12.06.08

http://www.debates.org/pages/news_092108.html. Accessed 04.10.08 